\title{
Green economy, subjektibotasun berdeak? Begiratu soziologikoa
}

Green economy, green subjectivity? A sociological approach

Jokin Bergara Eguren · bergarajokin@gmail.com

SOZIOLOGIAN DOKTOREGAIA EUSKAL HERRIKO UNIBERTSITATEAN

Recibido: 08/10/2018

Aceptado: 03/12/2018

\section{Laburpena}

Bizi dugun gizarte errealitatea, kapitalismo post-fordistak dituen egiteko eta egituratzeko moduen eraginpean dago. Arriskua, ziurgabetasuna eta ezegonkortasuna gailentzen dira eta norbanakoari eskatzen zaio bere izatearen zein kokapen sozialaren ardura bizkar gainean har dezan. Garai bateko diskurtso ekologista, kapitalismoaren logikaren aurreko praktika antagonikotzat har zitekeena, egiteko modu malguagoetan txertatu da, green economy fenomenoaren baitan. Bada, ikerketa honetan, Bartzelonako hirigune metropolitarrean kasuikerketa burutu dugu, elkarrizketen eta azterketa dokumental zein bisualaren erabilera eginez. Ekonomia berdearen arrakastaren giltzak zeintzuk diren arakatu nahi izan dugu, bere atzean gordetzen diren arrazoi eta prozesu psikosozialetan sakonduz. Bestelako proposamen eraldatzaileekin alderatuz, zein ondorio sozial dakartzan eta ze gizarte talderi begirakoa den bere jarduna arakatu dugu. Biztanleriaren gaineko kudeaketa biopolitikoak eta kapitalismoan sorturiko desberdintasun sozialek topo egiten duen lekuan kokatu dugu. Azkenik, bere izaera ez eraldatzailea jarri dugu agerian, Ecological Modernization Theroy-ren paradigmapean garaturiko teoria eta praktika zehatzaren artean dauden kontraesanak azpimarratuz.

Hitz gakoak: Green economy, ethopolitika, ingurugiro krisia, green subjektibazioa.

\section{Abstract}

We live in a society deeply influenced by the logic of the post-fordism capitalism, in our ways of doing and societal articulation. Risk and uncertainty are dominant in this logic. All the responsibility, related with our social position and reality, is in the shoulders of the individual. The ecologist discourse, that was antagonist to the capital logic in its origins, has been colonized by more flexible ways of proceed, in the form of the green economy. We elaborated a case study in the metropolitan area of Barcelona with interviews and documental-visual social research. We ask ourselves, what are the principal reasons that has allowed the success of the green economy, inquiring in the processes that hide behind. Comparing with other transformative approaches, we pretend to know what are the principal social consequences of its practice and who is it for. We have placed it in the point that biopolitical management of society and the reproduction of social inequalities inside capitalism find each other. To end we insist in its non transformative character, remarking its lack of coherence between Ecological Modernization Theroy and concrete practice.

Keywords: Green economy, ethopolitic, environmental crisis, green subjectivation. 


\section{MUNDU BERDEAN MURGILDUZ}

Gai ezaguna dugu honezkero aldaketarena. Geroz eta gutxiago dira azken urteetan bizi ditugun aldaketei entzungor egiten dieten zientzialariak, bai ekonomian, politikan zein kultura arloan eraldatzen ari dira geure egiteko, harremanak izateko eta pentsatzeko moldeak (Bauman, 2007; Castel, 2002; Laval eta Dardot 2013; Lorey, 2016). Honi guzti honi, erronka ekologikoa eransten badiogu garai aldaketa baten aurrean gaudela esan liteke, gizakiak sekula aurrez ikusi gabeko erronkei aurre egin beharko baitie antropozenoaren aroan (Lewis eta Maslin, 2015).

Geure gizarte garaikideak, antolakuntza molde kapitalista eta post-fordista bizkarrezur edukirik, euren iraunkortasuna bera jarri dute zalantzan (Jackson, 2009). Aldaketa klimatikoaren zenbait ondorio, ikusgarri dira dagoeneko, eta iritzi publikoa erakundeen erantzunak eskatzen ari dela nabaritu dezakegu, neurri ekonomiko-administratiboren bat har dezan, erronka eko-sozial erraldoiari nolabait ere adarretatik heltzeko. Mendebaldea dei genezakeen munduko lur zati honetan, erakunde eta gobernu ugarik azaldu dute ekonomia berdea sustatzeko eta eraikitzeko beharra, erregai fosilen menpekotasunetik at jardun eta iraun ahal izango duena (Davies eta Mullin, 2010).

Green economy deritzon fenomenoa agertu zaigu, bada, azken hamarkada hauetan. Ekoizteko eta kontsumitzeko «bestelako» modu gisa aurkeztu zuen bere burua hastapenetan, kontsumoa ez zedin kaltegarri izan biosferarentzat ez eta geure gorputzentzat ere. Ekintzaile neoliberalek geure gizarteen erritmoak ezartzen dituzten garaiotan, edozein merkatu eremu izan behar du eskuragarri, erabilgarri, diru-iturri. Ekintzaile arrakastatsuen zain balego bezala, ekonomia berdea duela gutxira arte esplotatu gabeko merkatua izan da. Merkatu berdearen garapena, noski, bizi ditugun beste zenbait prozesu sozialekin loturik iritsi da, norbanakoaren gorputzarekiko kezka eta etengabe hobetu beharraren dogma kasu, zeinak gizartearen kudeaketa biopolitikoaz hitz egitea ahalbidetzen digun, hertsiki lotua, betiere, jarduteko modu kapitalistarekin (Foucault, 2009).

Ze gizarte fenomeno gertatu da hemen? Bada, ezin daiteke esan gizarte zientzien arreta erakarri ez duenik merkatu berdearen zabaltze eta egonkortze honek. Soziologia, antropologia, geografia edo ekonomia politikotik ekarpen ezberdinak egin izan dira, bakoitzak bere esparrutik, baina guztietan ere kokapen teoriko zehatzak marraztuz, jarraian azalduko ditugunak.

Esku artean duzun ikerketa honetan, fenomenoarekiko interesak bultzaturik, galdera hauek egin dizkiogu geure buruari: egunerokotasunean nola garatzen da? zein arrazoi psikosozial edo prozesu soziali erantzuten dio? zein ondorio soziologiko dakartza? Zeintzuk dira euren jardunaren atzean gordetzen diren diskurtso-ildo nagusiak?

Ekonomia berdeaz hitz egiten hasiz gero, hortaz, ea ekonomia gauzatzeko modu berria den arakatuko dugu, zein logikaren barruan kokatua dagoen eta zein eratan egiten dituen 
bere agerpen zehatzak, geure kasuan, Bartzelonako auzo ezberdinetan burututako kasuikerketaren bidez.

Datozen orrialdeetan, green economy gisa ezaguna dena nola definitu izan duten aztertuko dugu, joera teoriko ezberdinetara hurbilduz. Jarraian, burutu dugun kasu-ikerketa aurkeztuko dugu, azalpen soziologikoak ekarriz fenomenoa ahalik eta xeheen ulertzeko zientzia sozialetatik. Bukatzeko, ondorioen aurkezpena egin da, green economy-aren inguruan dauden hurbilpen teorikoen eztabaidan sartuz, identifikatu ditugun logika eta jardun moldeetan oinarritu ondotik.

\section{ZER DA GREEN ECONOMY-A?}

Gizarte zientzietan eztabaida korapilatsua sortu duen galdera da formulatu berri duguna. Eskola eta korronte teorikoen arabaera, definizio ezberdinak eta zenbaitetan kontrajarriak aurki ditzakegu. Jarraian, egon diren hurbilpenak zerrendatu eta sakonduko ditugu, egoera teorikoaren argazkia izan dezagun.

Lehenik eta behin, Modernizazio Ekologikoaren Teoriarekin (Ecological Modernization Theory, EMT jatorrizko izendapenean) egin dugu topo. Paradigma egiturazko-funtzionalistaren baitan kokatu dezakegu formulazio hau, zeinetan, green economy-a uztargarria ikusten duten garapen industrialean, hazkuntza ekonomikoan eta kontsumo arduratsuan oinarrituriko antolakuntza sozial eta ekonomiko batekin (UNEP, 2011).

Merkatu berdeari gorazarre egiten diote nolabait, krisi klimatikoari erantzun eraginkorra emateko tresna bailitzan. 80. hamarkada erdialdera garatu zen teoria hau, Europa mendebaldeko herrialdeetan bereziki. Berau eraiki zuten akademikoek, ingurugiroarekin loturik zeuden praktika sozialak azaldu nahi izan zituzten, zer nola ulertzen genuen eta bere aurrean hartzen genuen jarrera ikertu nahian. Euren helburu nagusia, praktika berdeak (merkatu berdeen agerpena alegia) gizarte modernoetan eraldaketa esanguratsuak nola eragin zitzaketen identifikatzea izan zen (Benton, 2002: Cohen, 1997: Redclift eta Woodgate, 1997: Mol eta Spargaaren, 2002).

Korrontearen defendatzaileek diotenez, merkatu ekonomiak gaitasuna du baldintza eta egoera berrietara egokitzeko, beraz, ez da traba izango gizarte jasangarriagora iristeko prozesuan, are, helmuga horretara bidea egiteko ezinbestekoa izango da. Modernizazio prozesuak aurrera egin ahala, gaitasun erreflexiboa areagotuko zaigula diote, geure burua zehatzago aztertu ahal izango dugula, gizartean kontzientziazio maila askoz altuagoa erdiesteraino. Era honetan, garapen teknozientifikoaren, berrikuntzaren eta erakundeen esku-hartzearen bidez, gizarte industrial kutsatzailetik gizarte industrial berdeagora igarotzea posible izango omen da, erregai fosilak erabili beharrik gabe edo behintzat askoz ere neurri txikiagoan, ingurugiroaren eta gizartearen arteko harreman harmonikoa lortuz (Huber, 1991, Givens et al. 2015). 
Iturri teoriko honetatik asko edan izan dute erakunde nagusiek, Europako gobernu garrantzitsuenek, masa-komunikabideek eta oro har diskurtso sozial hegemonikotzat jo dezakegunak. Dauzkagun erronka sozio-ekologikoen aurrean ekiteko modu gisa hobesten da, Green growth strategy dokumentuak, argi adierazten digun legez; Ekonomia Lankidetza eta Garapenerako Antolakundea osatzen duten estatuek sinatua (OECD, 2011).

Bigarrenik, azaldu berri dugun EMT-aren korronteari kontrajartzen zaiona, bere etsai historikoa da, korronte neo-marxista edo ekosozialista dei dezakeguna. Kapitalismoari egiten dioten kritika zorrotzetik abiatuz, green economy-aren kontraesanak azaleratzen saiatzen dira. Green economy-a interes kontrajarriak desagerrarazteko saiakeratzat jotzen dute; alde batetik interes ekologista legoke eta bestetik arrakasta ekonomikorako gosea, ezin bateragarritzat jotzen dituzten arren, ekonomia berdea bi praktika hauek uztartzeko ahalegina dela esango dute, koherentzia eta zilegitasunez jantziz (Brand, 2012).

Mesfidatiak dira oso, merkatu jardunean oinarritzen den gizarte antolakuntza modu bati kutsu berdeagoa eman nahi zaienean (Pellizzoni, 2004). Egungo arazo eta erronka nagusien funtsa kapitalismoaren erak direla azpimarratzen dute, jasangarritasun ekologikorako bidean, kontuan hartu beharrekoak direnak ezinbestez. Modernizazio Ekologikoaren premisak zalantzan jartzen dituzte, kapitalismoaren oinarriei aipamenik egiten ez dietelako, kausa nagusienetako bat hori denean korronte ekosozialistarentzat. Karl Marx-ek duela mende eta erdi defintu zuen kapitalaren akumulazio prozesuak indarrean jarraitzen duela defendatzen dute, sarraski sozio-ekologiko izugarriak eraginez oraindik ere. Logika honen baitan, kapitala da gizarteen enborra eta bai lan-indarrak zein baliabide naturalek bere hazkundea elikatu beharra daukate, geroz eta eraginkorragoa izan dadin akumulazio prozesua (Foster, 1999). Diotenez, logika eta egiteko modu horien zurrunbiloan jarraituz gero, planetaren mugak gainditzea ez den beste aterabiderik ez dago, milaka urtetan zehar biziraun duten ekosistemak lehortuz eta natura zikloetan arrakalak sortuz (Foster et al., 2010).

Green economy-aren eraikuntza prozesua aztertu duten ikerketak egin dituzte eremu horretatik. Erakutsi dutenez, "garapen jasangarriaren» ideia apurka-apurka merkatuak eskatzen dituen prakitka eta logiketan sartu da (Slocombe, 1998). Horretarako, beharrezkoa izan da merkatu berdearen artikulazioa eta egonkortzea. Inbertitzaileen, burokraten, teknikarien, ekintzaileen eta politikarien arteko harremanak birdefinitzeko balio izan du. Ingurugiroaren gaia kudeatzeko era bat txertatu da azken finean, jasangarritasunaren diskurtsoaren aterkipean. Hazkunde ekonomikoa eta ingurugiroaren babesa bat datoz garapen iraunkor berdearen proiektuan, orain gutxi arte baterazintzat jo izan badira ere (Musu, 2009). Ekosozialistek oso argi dute nazioarteko elite batzuk osturiko sareetan erein dela merkatu berdearen hazia, negozio borobila jopuntutzat harturik. Marka, enpresa multzo handi eta finantza funtsen arteko kapital-ibilbide berriak sortu dira merkatu berdeari esker, herri klaseen poltsikoek igarri ez badute ere (Miller, 2003, 2005). 


\section{EKINTZAILETZA ETA KONTSUMO BERDEARI BEGIRATUA}

Badira urte batzuk jadanik, Europako nazio.estatu nagusienek baliabide berriztagarri eta kutsadura atmosferiko maila baxua duen ekonomia baterantz jauzi egiteko asmoa erakutsi dutenetik. Nolabait ere, aurrez deskribatu dugun ekonomia green horren paradigma ezarri nahi da, betiere gaur egun europar gobernuek otzan-otzan jarraitzen dituzten ordena neoliberalaren irizpideen barnean, hazkuntza etengabea eta kontsumo politikak zalantzan jarri barik (Bina, 2013; Philips, 2013).

Horrenbestez, ez dezakegu bazterrean utzi green economy eta proiektu neoliberalaren arteko uztarketa ia perfektua deneko ideia, merkatu bide berriak irekitzen baititu, kapitalak hazteko eremua izan dezan, ostera ere. Naturaren kudeaketarako modu zehatz baten aurrean geundeke hortaz, baliabideak eta naturaren gainean eraikitzen ditugun diskurtso sozial nagusiak baldintzatuko dituena (Tienhaara, 2014).

Zeintzuk ditugu, ordea, eremu berde berritzaile eta ekintzaile hauetan, murgiltzen diren norbanakoak? Zein ezaugarri soziologiko dituzte? Zein eratan dute euren buruarekiko definizioa eraikia? Zein motibaziok gidatuta dabiltza ekonomia berdean lanean?

Lehenik eta behin, esan beharra dugu badirela ikerketa zenbait subjektibotasun hauek arakatzen saiatu direnak. Oro har, gehientsuenek diote, ekonomia jasangarriago bat sortzeko asmoak gidatzen dituela, eta baita ere, noski, dirua pilatzeko nahiak (Jolink et al. 2013; Schaltegger, 2002). Nabarmentzekoa den puntua azaltzen digute autore hauetako batzuek; diotenez, neoliberalismoak ekintzailetzat jotzen duen pertsona mota era borobilean gorpuzten da hemen; pertsona ausarta, diziplinatua, langilea... arrakasta lortuko duena izerdia litroka isuriz gero. Green eremua izanagatik, patroi diskurtsibo hauek errepikatzen direla identifikatu dute (Nijikamp, 2003).

Praktika eraldatzailetzat joko dute euren jarduna, ekintzaile tradizionalaren ereduari jasangarritasunaren ikuspuntua eransten baitiote (Rodgers, 2010). Era berean, badaude ikerlanak, zenbait esparrutan eragile sozial-aren ideia egon badagoela ondorioztatu dutenak (O’Neill eta Gibbs, 2016). Kasu hauetan, ekintzaile berdeak dei ditzakegunek, euren negozioa beste zenbait jarduerarekin uztartzen dute, kontzientziazio soziala helburu (hitzaldiak, mahai-inguruak etab.). Finean, kontsumo praktikei ikusmolde jasangarriagoa erantsea da pertsona horien ekintzailetza soziala, kontsumo «kutsagarrietatik» «jasangarrietara» jauzi eginez.

Ikus dezakegunez, diskurtso berdeak hedapena izan du eremu hauetan, betiere arrazionaltasun eta egiteko modu neoliberalen baitan kokaturik. Green gisa defini dezakegun ingurune sozialak, bere burua eraldatzailetzat jotzen du, ekintzailetasunari buruzko beste ulerkera bat garatuz, neoliberalismotik haratago doana, zeinak norbere etekin pertsonaletik harago doazen ekintzailetza ereduak badaudela dioen (Gibson-Graham, 2008). Defi- 
nizio horiek identifikaturik, ez legoke soberan geure buruei galdetzea, ea nola den posible egungo testuinguru neoliberalean, green economy-a eraldaketa sozial, ekonomiko eta ekologikorako tresna izatea, halakorik balego.

Datozen orrialdeetan, galdera honen erantzuna marrazten saiatuko gara, green ekintzailetza hau posible egiten duten prozesu sozialak zein diren identifikatuz; nori zuzendua dagoen eta zein ondorio dakartzan deskribatzeko ahalegina da ondorengoa.Kasu-ikerketa, green sektorearen errotze eta zabaltzea Bartzelonako hirigunean.

Ikerketa aurrera eramaterako orduan, kasu-ikerketaren formulan oinarritu gara, genuen ikergaiarentzako metodologia aproposena zela iritzita (Yin, 1994; Gerring, 2004; VanWynsberge et al., 2007). Zehazki, Europako hiri esanguratsuetako bat aukeratu dugu, Bartzelona, duen dimentsioagatik eta aniztasun sozialagatik, Europako hiri nagusietan garatzen ari diren zenbait prozesuren lekuko izaten ari baita. Green1 negozioan dabiltzan merkatalguneak, dendak eta oro har negozioak aukeratu ditugu, Bartzelonako inguru metropolitarrean kokatuak guztiak ere.

Kasu-ikerketek, bestelako jakintza sozial guztien gisan, murgilduta dauden testuingurutik eraikitzen dute ezagutza, hortaz, eraiki dugun jakintzaren testuinguruzko izaera, ikerlariak izan dituen harreman eta bizipenek baldintzatua, onartzen dugu. Alabaina, gizarte zientzia egiteko saiakera denez honakoa, ahalik eta zorrotzen ekiten ahalegindu gara, jaso dugun informazioarekin eta erabili ditugun teoriekin, egon zitezkeen eragin ideologiko, politiko edo aurreiritzizkoak neutralizatuz ahal zen neurrian.

Geure lan enpirikoa, alde batetik sei elkarrizketa ezberdinetan oinarritu da. Berauek aukeratzeko irizpidea, green sektorearekin harreman zuzena duen pertsona izatean oinarritu da, izan supermerkatu kate handi bateko arduraduna edo eskala txikiagoko dendetako saltzailea. Hautatu ditugunek, negozio berdean murgildurik dagoenaren perfila izan zezan saiatu gara, iruditu baitzaigu inguru sozial horretan eguneroko harremana eta kontaktu zuzena duten pertsonengandik informazio aberatsa lor genezakeela elkarrizketen bidez, inkesta bidez edo bestelako datu-jasotze teknikaren baten bidez baino.

Azpimarratu beharra daukagu green alorreko negozioez ari garenean, produktu ekologikoen salmentan oinarritzen den jardunaz dihardugula, izan elikadura arloan, kosmetikan edo farmazian. Interesgarria iruditu zaigu sarean dauden diskurtsoetan arakatzea, ze irudi motarekin aurkezten diren, zein bezero motari zuzentzen zaizkion etab. Soziologia bisuala, neurri oso baxuan, egin nahi izan dugu ere. Merkatu berdean dauden kate adierazgarrienen bilaketa bat burutu dugu, euren tamainaren, fakturazio mailaren eta komunikabideetan duten oihartzunaren arabera izan dira aukeratuak. Euren diskurtsoen zatiren bat hartu dugu ikerketarako, bai eta darabiltzaten irudi mota pare bat ere, informazio bisual aberasgarria eman dezakeelako esperantzan. 
Elkarrizketatan parte-hartu zezaketenak, green elkarteen bilaketa online baten bidez identifikatu genituen, web-orrialde ezberdinen bidez «Barcelona ecológica: tiendas, restaurantes, bares y mercados. Lugares para comprar, comer y beber respetando el medio ambiente» ${ }^{1}$.

Era berean, elur-bolaren teknika ere erabili genuen, bai eta behaketa ere, gisa honetako negozioak identifikatuz eta ikerketarako egokiak izan zitezkeenak aukeratuz.

Onartzen dugu, metodologia kualitatiboa eta zientzia soziala izaki, burutu ditugun elkarrizketak ez direla unibertso osora aplikagarriak, baina bai sinesten dugu jasotako informazioaren izaera baliotsu eta aberatsean, bai eta green inguru sozialean eraikitzen diren patroi diskurtsibo zenbait identifikatzeko gaitasunean.

\section{GREEN ECONOMY-A AZTERTUZ}

Green economy-a posible egin duten arrazoi psikosozialak ezagutu guran, azterketa enpirikoa lau azpiataletan banatu dugu. Iruditu zaigu, era honetan gaitasun azaltzaile handiagoa lortu dugula, lau prozesu ezberdinei buruz ari baikara. Azpiatal bakoitza, elkarrizketatuek emandako gako eta iritzi sorten arabera eraiki da, betiere aurrez egindako irakurketa akademikoarekin eta erabili dugun marko teorikoarekin loturik, bistan denez.

Jaso ditugun kontaketa zenbaiten gainean, bizitzaren gaineko politikek zein eragin duten islatzen saiatuko gara, eta green economy-aren praktikak eraldaketa soziala helburu duten mugimenduekin zein harreman eta ondorio dituen hausnartuko dugu.

Bi ideia nagusi garatu ditugu fenomenoaren azalpenean Eko-abangoardia eta Green kontsumoa, bizitzaren gaineko gobernantza izenburupean bildu ditugunak:

\subsection{Eko-abangoardia}

Eko-abangoardia kontzeptua ekarri nahi dugu ikerketa honen azalpenera, egokia iruditu baitzaigu aztertzen dihardugun fenomeno sozialaren berri emateko. Kontzeptu honen bidez, ekonomia berdearen biderkatze eta errotze sozialaren arrazoietan araka dezakegu, batez ere Bartzelonaren ezaugarri antzeratsuak dituzten hirigune handietan. Proposaturiko ideia, bi alditan garatuko dugu; lehenbizi Ezaugarri kontra-hegemonikoen xurgapena atalean sakonduko dugu eta bigarrenik Green subjektibazio garaikidea izenburupean.

\subsubsection{Ezaugarri kontra-hegemonikoen xurgapena}

Kolektibo edo talde-osaerekiko izan ordez, norbere buruarekiko ardura hartzeak betetzen du subjektu garaikidearen izaera (Bauman, 2017). Lehiakortasunak, malgutasunak eta la-

\footnotetext{
${ }^{1}$ https://www.timeout.es/barcelona/es/que-hacer/barcelona-ecologica-tiendas-restaurantes-bares-y-mercados
} 
nera begirako bizimoduen logikak, gizarte bizitzaren alor guztietan bila dezake itzalik. Norbanakoaren arrakastaren bueltan eraturiko diskurtsoak, ezinbestez, ibilbide propioak goresten ditu, norberarekiko miresmen dosiak behar ditugu norbere buruaren kudeaketaren ardura hartu beharra du norbanako garaikideak, izan ditzakeen bizi-aukeren hobekuntza etengabea bilatuz ${ }^{2}$ (Lupton, 2016: 68). Ez kasualitatez, patroi diskurtsibo berdintsua aurkitu dugu ekonomia berdearen inguruan eginiko elkarrizketetan, baldintza sozioekonomiko berrietara egokitzeko gaitasunarekin eta merkatu eremu berriak eraikiz.

Hala, negozio berdearen biderkatzearen arrazoiez galdetu dugunean, «moda» hitza behin eta berriz azaldu zaigu, gomendagarri den praktika hegemoniko gisa, onespen eta prestigio sozialaren lorpenarekin lotua dagoena.

«Yo veo, al final, que también es algo comercial ¿no?, es algo, como digo... por la moda pues han aparecido por todos los sitios estas tiendas...» (E5)

«Es verdad que se pone un poco de moda también, peo bueno, chapó no? Que se pongan de moda estas cosas que traen beneficio para todos antes que otras. Creo que definitivamente esto está en aumento y que cada vez irá a más...» (E1)

Iritzi hauek agertu zaizkigunean, geure buruari galdetu diogu ea zein arrazoi egon litekeen hastapenetan jardun minoritario eta bazterrekoa zen batek (kontsumo ekologikoa kasu) arrakasta zantzuak izateko, sozialki onetsia, eta kapitalismo garaikidearen sareetan horren ongi loratua. Hau azaltzeko, egokia iruditu zaigu Eko-abangoardia izena erabiltzea.

Michel Foucault pentsalariak esan zigun gisan, esan liteke biztanleria kudeatzeko teknologia zehatza garatu dela, zeinak norbere enpresari izatea eskatzen duen, besteengandik bereizi eta izaera-zerbitzu berriak sortzeko (Foucault, 2009). «Ni»-a da geure kokapen soziala hobetzeko daukagun bide bakarra, esaten zaigunez. Nitasun nartzisista zaigu berehalako helburu, taldeko babes sareetatik at geratu gara, norbere ibilbide profesionala bilakatuz existentziaren arrazoi eta ondorio (Fraser, 2015; Lasch, 1999). Proiektu neoliberalarekin bat datozen subjektibotasunak eraikitzeko beharra du gizarte garaikideak (Sennet, 2000). Gizakiak sorkuntzarako duen gaitasuna, funtsezko faktorea izan da edozein mugimendu sozial, politiko edo artistikoren garapen eta loraldian. Abangoardia artistikoek, mugimendu kritikoek edota kontrakultura gisa sailkatzen dugun mugimenduak ezaugarri aipagarriren bat baldin bazeukaten, sorkuntza eta orijinaltasuna zen, berritasunaren agerpena, eskemak hausteko ahalmena. Egun indarrean dauden logikek, kapitalismo post-fordistaren baitan koka ditzakegunak, sorkuntzarako gaitasun hori xurgatua izatea ahalbidetzen dute. Bere jaio une historikoan kontraboterea eraikitzeko eta bestelako errealitate eraldatzaileak sortzeko izan zezakeen ahalmena galdu du, etenik ez duen gurpil zoroan murgiltduz. Hirigune zehatz batzuetan bizi diren gizarte taldeen arreta erakarriz, kontsumo ekologikoak izaera selektiboa hartu du. Kontsumitzaile, dirudun,

\footnotetext{
${ }^{2}$ Itzulpen propioa.
} 
mokofinari, herri-klaseetatik bereizteko aukera zabaltzen dio merkatu berdeak (Rendueles, 2013).

Jardun kontrakulturalak edota abangoardia artistikoenak, apurketarako gaitasuna zuten, sorkuntza bide horretan erabili nahi zen. Egun, ordea, jardun kreatibo apurtzaile horiek, Deleuze-k esango lukeenez, kapitalismoaren axiomatikak xurgatuak izan dira (Deleuze, 1987). Mekanismo berri horren bidez, kontsumo mota ezberdindu eta bereizia eskaini zaio hiriguneetan bizi den klase ertain-altuko jendeari, jatorrian zuen oinarrizko kritikatik aldendurik.

Logika komertziala gailentzen da elkarrizketatuen ahotsetan, ez dago oinarriko kritikarik, merkatu jarduna dute sostengu eta ipar. Berritzea, berrasmatzea, ekintzaile izatea eta kontsumitzea dira, ustez eraldatzailea den inguru honetan, agertu zaizkigun oinarri diskurtsibo ukaezinak. Kontsumitzaileari zerbait ezberdina eskaintzea, beste inork eskain ezin lezakeena da, azpimarragarria iruditu zaigun puntuetako bat.

«...constantemente nos encontramos en un proceso de innovación. Desarrollamos nuevos productos que no estaban disponibles en el mercado con certificación de producción ecológica, así como la optimización de la formulación de algunos productos para ofrecer al consumidor la mejor calidad y propiedades nutricionales.» (Web orrialdeko aurkezpena)

«No se trata tanto de reducir el consumo, no está enfocado a esto, sino que elijamos bien lo que consumimos, pues esta es la idea no?...» (E1)

Bereizteko, merkatuan nortasun propioa garatzeko ahalegina nabari dugu. Norbera ezagutarazi behar da merkatuan, lekua egin, besteekiko lehian sartu eta itxura erakargarriagoa hartu. Portaera sozial hau, aztertu eta ederki azaldu digute arrazionaltasun neoliberalaren gaineko ikerlanean Pierre Dardot eta Christine Laval-ek (Laval eta Dardot, 2013).

Prozesu paradoxikoaren aurrean gaude horrenbestez. Esan genezake ordena hegemonikoari kritika egiten zitzaion eremu sozial horrek (abangoardia, kontrakultura, pentsamendu kritikoa), hala nahita edo ez, green negozioaren sorreran eta hedapenean lagundu duela. Nolabait ere, oinarrizko adostasuna egon da masa-kontsumo eta bazterreko praktika kulturalen artean (Rendueles, 2013), kontsumorako lurralde berria irekiz, non gizarte talde zenbait subjektibatu daitezkeen. Nortasuna eraiki dezakete kontsumo esparru horietan mugituz, besteengandik bereiziz, Hipster kultura azpiurbanoak kasu (Ikus «Green subjektibazioa» azpiatala).

Ezkontza artifizial xamarra izanagatik (masa-kontsumo eta bazterreko praktikena, alegia), kontsumo gosea eraikitzeko balio izan du, hiri-eremu zehatz batzuetan bederen. Modaren bueltan diharduten komunikabideek, azken joeren kultura arina sustatuz, oinarri diskurtsibo ezin aproposagoa eraiki zuten masa-erraldoietik ezberdindu gura zuenak aukera izan zezan. Hala, bazterreko praktika kulturaletako ezaugarriak bereganatu eta kontsumo 
mota berria eskaini zuten. Mugimendu ekologistak edo eko-sozialismoak, pentsamendu kritikoaren edo bazterreko kritikan kokatzen zen mugimenduaren barruan egonik, prozesu hau lehen eskutik bizi izan du.

Kontsumitzaile mokofinak, ilustratuak, ikasiak eta kultura maila txukunekoak bilatuz, diskurtso zehatza eraiki zuten. Euren produktuek, kontsumorako oinarri sozial bat izateko saiakera dago azpian, eta neurri handi batean, kontsumo berdeak duen maila ikusirik, prozesu arrakastatsua izan dela aitor dezakegu. Kontsumo fin eta sofistikaturako oinarri ideologikoa eman ez ezik, gentrifikazio prozesuak azkartzen ditu, bizi diren auzo eta hirietako prezioek gorakada itzela izaten baitute.

Kultura azpiurbano horiek, kontsumitzerako orduan selektiboak direnak oso, bereizketa kultural eta gentrifikazio prozesuan eragile nagusienetakoak dira (Lopez-Gay, 2008). Europako hiri nagusienetan bizi dira, nazioarteko klase ertain-altuetatik datozen gazte-helduek osaturik gehientsuenetan. Subjektu kolektibo horiek era askotara izendatu izan dituzte, oro har errorik gabeak eta esperientzia zein bizipen berrien bila dabiltzanak sarri asko, Young Professionals edo Bourgeois Bohemian (Lopez-Gay, 2008).

\subsubsection{Green subjektibazioa}

Hiri klaseen bereizketarako lur ongarrituaren aurrean geundeke beraz. Bertan arakatzen hasirik, hautemate sozialaren eraldaketa nola gauzatu den ikusi ahal izan dugu. Bezero motatik hasi eta nagusi ziren diskurtso sozialen aldaketaraino, onarpen sozialerako ibilbidea egin du aztergai dugun praktikak. Hasiera batean egintza estigmatizatu eta bazterreko izatetik, ia hegemoniko bihurtzeraino:

«...Antes era un público determinado, venía gente que ya estaba informada y va ahí ¿no?, el resto decía como que raro, que es eso... hace diez años era un poco así. Son tiendas raras, caras para gente caprichosa, hippies no sé que... no ahora es para un público muy amplio...» (E3)

«A ver... también la gente del barrio que vienen, es gente que tiene una mejor economía también...» (E6)

«A veces hay gente de otros países que tiene interés por estos productos, franceses e italianos un montón...» (E3)

«...es lo que te digo... tampoco viene gente extranjera de todas partes, pero Francia y Alemania que son dos grandes productores de producto ecológico, muchas marcas que son de allí, lo agradecen...» (E2)

Jaso ditugun erantzun horien ondotik, aproposa iruditu zaigu kontsumitzaileen tipologia bat marraztea. Oro har, erantzunetan, jende gaztea dela, Europar iparralde edo erdialdetik datozela eta denboraldi baterako Bartzelonan daudela jaso dugu. Azpimarratu digute- 
nez, Herbehere edo Alemania moduko herrialdeetan, jasangarritasunaren kultura hedatuago da gurean baino, belaunaldi berrien aldetik gutxienez.

Ideia horren bueltan jiraka, elkarrizketatuen borondatea sumatu dezakegu, jasangarritasunaren kultura eta produktu ekologikoen kontsumoa lotzea xede duena. Agian, geure buruari egin beharko geniokeen lehenbiziko galdera horixe bera da, zergatik dauden horrenbeste europar, eros-ahalmen altu xamarrarekin, Bartzelonako gentrifikazio prozesuak sustatzen. Prezioen neurriak asko lagun diezaguke kontu hau argitzen. Aztertu ditugun negozioetako salneurriei begiratuz, berehala ohartuko gara bikoiztu edo hirukoiztu egiten dituztela ohiko dendetako prezioak ${ }^{3}$. Produktu berdeek, ez dute edozein erosle onartzen, esparru sozial jakin batetik eratorriak behar dute izan, Bourdieu-rekin esateko, kapital sozial, ekonomiko eta kultural txukuna behar dute, bai zaletasun hori edukitzeko zein euren burua errealizatua sentiarazteko gune green horietan.

Bourdieuk kapital mota ezberdinen inguruan daukan azalpena oso baliagarria zaigu aztergaiari azalpen soziologikoa eransteko. Esana dugu, kontsumitzailea gaztea dela, europar herrialde aberatsetatik etorria eta eros-ahalmen altukoa. Hiru kapital mota, gutxienez, topa ditzakegu zeharka, horren sinplea dirudien errealitatean.

Lehenik eta behin, gazte hauek denda green-etara etor daitezen, motibazio bat, esanahi bat, zentzu zehatz bat atxiki behar diote egiten ari direnari. Noski, mundu ulerkera jakina garatzen dute, errealitatean era batera jardutera daramatzana. Mundu ulerkera eta jokatzeko modu honek kapital kulturalarekin du zerikusia, jaso duten hezkuntza, irakurri dituzten liburuak, egunerokotasunean ingurukoekin dituzten eztabaidagaiak etab. Jasotako informaziotik ondorio horretara irits gaitezke zeharka, kezka eragiten dien gaia dela jasangarritasunarena, euren inguru sozialaren agendaren barruan dago, nolabait. Horren inguruan hausnartu eta eztabaidatzeko baldintza sozialak izan dituzte, kontsumitzaile green-aren portaera hartzera eraman dituelarik.

Aipatu azalpena, aldaketa klimatikoaren edota ingurugiro krisiaren gain ekiteko borondatea agertu dutenei aplikatu diezaiekegu, izan ere, kapital kulturala da beste kapital motekiko gailentzen dena, eta euren ekintza zein jokabideen azaltzaile nagusia.

Soziologo Frantsesak maisuki azaldu zigun bezala, norbanako bakoitzaren portaera sozialak hertsiki lotuak daude bere gauzapenerako baldintzekin, alegia, izan ditzaketen edo garatu ahal izan dituzten kapital mota ezberdinekin. Beraz, esan gabe doa hiru kapital motak elkarren artean loturik daudela, elkar-elikatzen duten prozesu etengabean murgildurik.

Geurera ekarriz, produktu berde-ekologikoak kontsumitzeko hautua egin izanak, kapital sozial edo harreman-sare jakina mantentzeko nahiarekin lotura dauka, hots, kontsu-

${ }^{3}$ http://www.eldiario.es/economia/Existe-burbuja-precios-productos-ecologicos_0_453554819.html 
moaren bidez subjektibazio zehatza garatzea, identitate urbano batean edo bestean identifikatua izateko (Bauman, 2007).

Burutu dugun lan enpirikoari jarraiki, egokia deritzogu kapital sozialaren kontzeptua ekartzea azalpenera, status edo kokapen sozial zehatz bat mantentzeko nahiarekin lotua baitago, aurrez Hipster, Young Professionals edo Bourgeis Bohemian gisa definitu ditugunak. Norberak izan dezakeen kapital sozialak, Bourdieuk adierazi zigunez, harreman-sare eta baliabideetara iristeko aukerak eskaintzen ditu. Hala, green kontsumoaren bidez identifikatu dugun subjektibazio prozesuak, harreman sare zehatzetan mugitzeko eta gizartearen aurrean irudi jakina islatzeko guraria dakar. Gutxi-asko, Bourdieu-ra joz ostera ere, borroka sinboliko bat litzateke, talde sozial errekonozitu bateko partaide gisa identifika ditzaten (Bourdieu, 1999).

Identitate kolektiboen eraikuntza prozesuen ohiko ezaugarria izaten da bereizgarri batzuk bereganatzea, estetika zehatza eraikitzeko eta kokapen sinbolikoa lortzeko, beste gizarte taldeetatik bereizia betiere. Hala, inguru green horietan erabiltzen dituzten eskuorriek edota dokumentuek kolore berde-marroixkak hautatzen dituzte oro har, euren esanahi soziala naturarekin harremana izanik, hain justu. Eraikuntza sinboliko partikularra dagoela antzeman dezakegu, mendiarekin, basoarekin eta lurrarekin lotura irudikatzen saiatzen dena (Jarraian, kasu-ikerketan jaso dugun dokumentazio bisualaren lagin bat erakusten $\mathrm{da}^{4}$ ).

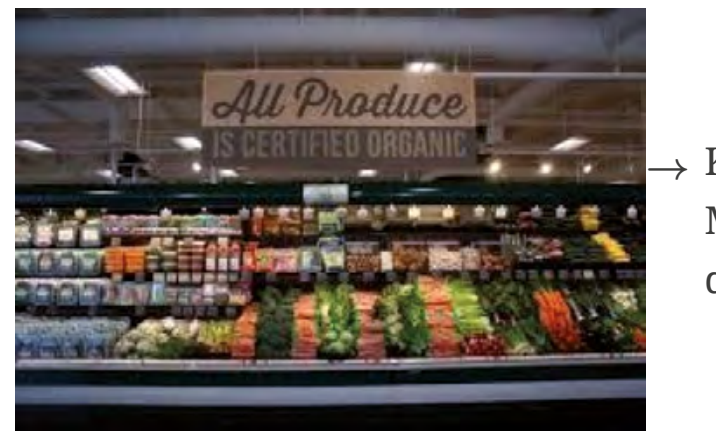

Kolorearen erabilera, produktuen antolamendua... Marketing operazioak lurretik atera berri diren produktua erosten zabiltzala eman gura du aditzera.

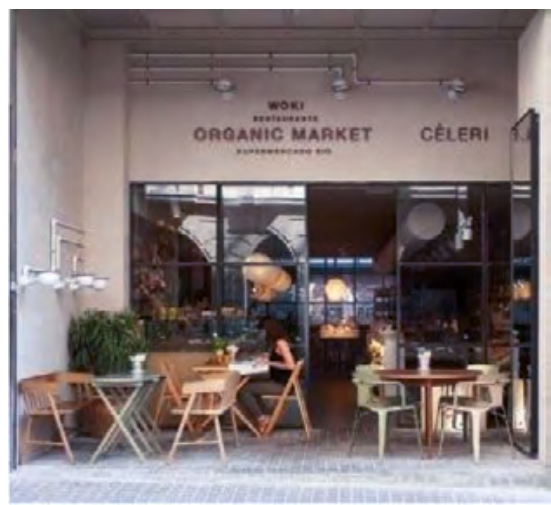

$\rightarrow$ Lokal hauen esperientzia estetikoak inguru sozial ezberdindua eraikitzea ahalbidetzen du, forma, izaera eta ezaugarri propioekin.

${ }^{4}$ Goian erakutsi ditugun irudiok, kasu-ikerketan zehar aurkitu diren edo webguneetan azaldu duten irudiak dira. 


\subsection{Green kontsumoa, bizitzaren gaineko gobernantza}

Bigarren ideia nagusira egingo dugu jauzi datozen paragrafoetan. Norbere buruaren kudeaketa eta bizitzaren gaineko politikekin zerikusia duen diskurtso-ildo esanguratsuarekin egin dugu topo. Azpiatal oso bat ildo hori lantzeari begira idaztea egokia iruditu zaigu, fenomeno berdearen agerpenaren faktoreetako asko koka baititzakegu ideia horren barruan. Zehazki, bi prozesuri buruz ariko gara, geure gizarte garaikideetan oso presente daudenak, portaera ethopolitikoa eta agertoki ziurgabeen ekoizpena, ingurugiro krisia kudeatzeko modu gisara. Hasi gaitezen bada, diskurtso honen nondik norakoak deskribatzen.

\subsubsection{Portaera ethopolitikoa}

Ez dira aipamen gutxi izan produktuaren kalitateari eta norberaren osasunari erreferentzia egin diotenak are, behin eta berriz errepikatu dute. Negozio modu klasikoaren eta eurenaren arteko ezberdintasun nagusia zein den galdetu dugunean (azken hau Green market-aren barruan ulertuz), norbanakoari ekartzen dizkioten onurak nabarmendu dituzte:

«...pues yo diría que la diferencia es que la gente que viene aquí se alimenta de esto, o sea, tiene como prioridad en su vida una alimentación ecológica de cultivos diferentes que no podemos encontrar en cualquier otro tipo de supermercado... » (E3)

«La calidad de producto, al final, la gente lo valora, porque saben que lo que compran aquí tienen garantías y que es saludable, aunque a veces nos guste el producto, porque por ejemplo, no se... el granel tampoco es que le guste a toda la gente, ¿sabes?... (E4)

«...Estamos muy intoxicados, todas las enfermedades que tenemos se inician por un exceso de toxicidad del organismo, porque estamos llenos de metales pesados, químicos... expuestos a todo tipo de contaminaciones... entonces nuestra idea es reducir esta toxicidad al máximo posible, no sólo por el medio ambiente sino por nosotros también , por un tema de salud.» (E1)

Era berean, enpresa berde hauetako batzuk nola aurkezten diren euren webguneetan aztertu dugu, osasunaren eta elikagaien balioa ekarriz behin eta berriro lehen lerroetara:

«Nuestros supermercados nacieron con un objetivo: hacer accesible a todo el mundo la mejor alimentación posible, la comida de verdad, ofreciendo la mayor variedad de productos al mejor precio y siempre con la certificación ecológica para garantizar una alimentación saludable y sabrosa. En definitiva, nuestros supermercados nacieron por la convicción de que era posible una alimentación mejor.»

Norbera balioan jartzeko prozesua geroz eta garrantzitsuago eta zabalduago den garaiotan, eraginkortasunaren eta errendimenduaren ideia nagusitzen da, subjektuak bere ba- 
lioa areagotzea bilatu behar du, hazi, indartu, osasuntsu izan. Diskurtso biomediko hegemonikoak zentzu horretan bideratzen ditu gizarte garaikide modernoetako partaideak, geure eguneroko jardunetaraino iritsiz, eko-bio produktuek dituzten ezaugarriak balioan jarriz, ia derrigorrezko kontsumo gisa. Bidenabar esan, gizartearen kudeaketa biopolitikoa elikatzen laguntzen duela zientziatik datorren diskurtsoak, biomedikuntzatik kasu honetan:

«...bueno el consumidor tiene en general esa tendencia a querer calidad del producto... como era antes, es que se nota en la calidad, sabes? Todos tendemos por nuestra propia naturaleza a querer lo más fresco y lo más natural...» (E1)

Puntu honetan, Foucaulten biopolitika kontzeptuaz (Foucault, 2006, 2009) eskola anglosaxoiak eginiko irakurketa interesekoa iruditu zaigu, zehazki Nikolas Rose eta berak definituriko ethopilitika kontzeptua (Rose, 2006). Biztanleriaren kudeaketa moldeak aztertzen dituen ikerketa eremuan kokaturik, Foucault-en eskolari jarraiki, (gobernamentaltasun eta biopolitikari buruzko azterlanetan bereziki) Rose kontzeptuok hartu eta egunerokotasunean ditugun praktiketara garraiatzen saiatzen da, osasunera, besteak beste. Ethopolitika hain justu, gizakion portaera definitzeko saiakera litzateke, geure autobegirada etikotik ekiten dugun unetik (Tirado, 2008: 336. o)

«La ethopolítica hace referencia a las autotécnicas con las que los individuos se juzgan y actúan sobre ellos mismos para mejorarse. Refiere estrategias a través de las que el ethos de la existencia humana (sentimientos, naturaleza moral, creencias) constituye el medio con el que el autogobierno del individuo autónomo conecta con los imperativos del buen gobierno.»

Rosen arabera, egungo bizitzaren gaineko gobernu moldeak, bere erabakietan fina eta selektiboa den subjektuaren gain dihardu. Subjektu garaikide horrek, bere kontsumo praktikek bizimodu osasuntsua eskain diezaioten gura du, ez da aseko bere behar fisiologiko oinarrizkoak elikatzearekin, gehiago eskatuko du. Informatuko da, exijituko du, arrazionaltasun zehatza garatu eta marko horretan hartuko ditu kontsumo erabakiak. Kostuetekin kalkulua etengabe agertuko zaio egunerokotasunean burutzen dituen aukeretan. Ekiteko modu hau zaigu nagusi subjektuak gobernatzeko modu berrietan. Subjektua erabat askea da bere erabakiak hartzeko, esango zaigu praktika horiek ahalbidetzen dituen oinarri diskurtsibotik.

Nolabait ere, norberarekiko ardura hartzeko prozesua azkartzen da. Botere-mekanismo honen bidez, subjektua ia behartua dago arriskuak kalkulatzera, bere gorputzaren kudeaketa egokia egitera, gaixotasunik ez garatzeko neurriak hartzera.

Diskurtso zientifiko nagusiak, biztanleria kudeatzeko estrategia horri elikagai aberatsa ahoratzen dio, nola edo hala, marra gorri zurruna eraikitzeko ahalmena baitu gomendagarri diren praktiken eta kaltegarri-arbuiagarri direnen artean. Zenbait erantzunetan, diskurtso zientifikoaren boterea gorpuztua nabari daiteke: 
«...también hay gente que viene cuando su salud está muy deteriorada... es gente con alergia, con enfermedad que le ha tocado fuerte. Necesitan productos ecológicos, porque aquí todo es ecológico con certificación y análisis y todo...» (E2)

Azken erantzun honetan esaterako certificación eta análisis hitzek, erreferentzia egiten diote kode zientifiko eta instituzional oso bati, produktu ekologikoen berme izango dena, ondorioz kontsumitzeko gai eta mesedegarri. Sare zientifiko erraldoi horrek, hortaz, praktika ekologiko-zale eta kontsumitzaile green horren legitimatzaile papera betetzen du, akademiaren prestigio sozialak nolabaiteko zilegitasuna aitortzen die. Zientziaren erregimen diskurtsiboak, egiaren monopoliodun izanez gaur egun, babesa eskaintzen dio beraz green kontsumoari, ez soilik gomendagarri egiten dutelako, mekanismo burokratiko oso bat jartzen dutelako martxan, produktu horiek, beren ziurtagiri eta azterketa guztiekin, bereizgarri bat izan dezaten, beste produktuek ez dutena.

Diskurtso horrek berak erabakitzen du, zer dagoen barnean eta zer kanpoan, produktu ekologiko-organikoak sailkatuz gizakiak bere osasuna zaintzeko, ongi sentitzeko eta betetatasunera iristeko duen kontsumo-bide gisa. Aldiz, diskurtso zientifiko honen irizpideekin bat egiten ez duten produktuek (kalitate eskasekoak, janari azkarra, koipeak...) subjektu ethopolitikoaren praktiketatik geroz eta aldenduago egoteko bidean daude.

Honenbestez, elkarrizketatuek osasunaren inguruan eman dituzten azalpenak marko etiko horren baitan kokatzen ditugu, subjektu garaikidea ezaugarritzen duena. Marko horren arabera neurtuko du bakoitzak bere jarduna. Dituzten praktikek marko horrekin bat egiten duten edo estigmatizatuak izan daitezkeen kontsumo praktikak dituzten epaitzeko neurria izango da, hain zuzen ere.

\subsubsection{Ziurtasunik gabeko agertokien eraikuntza eta Green kudeaketa}

Bestalde, biztanleriaren kudeaketa biopolitikoari hertsiki loturik, agertoki ziurgabeen eraikuntza prozesuak antzeman ditugu. Elkarrizketak bukatzerako orduan, elkarrizketatuei euren negozioen etorkizunaren inguruan zuten iritzia eskatu genien, testuinguru klimatikoak nola eragin zezakeen hausnar zezatela iradokiz. Arrisku biologikoen , iritzi katastrofisten eta itxaropen gabezia dakarten diskurtsoekin egin dugu topo, etorkizuna beltza irudikatuz, guztietan ere:

«...Mira, pues, este negocio ayuda a reducir la contaminación y a todo esto que está pasando... sí que es verdad que lo más durillo es cambiar la mentalidad de la gente, pues por ejemplo están consumiendo bolsas continuamente, hay algunos que traen las suyas pero la gente en general no lo hace... es difícil...» (E2)

«...Creo que hay un peligro medioambiental y a nivel de salud se refleja no? Estamos muy intoxicados, todas las enfermedades que tenemos se inician por un exceso de toxicidad del organismo, porque estamos llenos de metales pesados, químicos... expuestos a todo tipo de contaminaciones...» (E1) 
«... a ver pues yo creo, pero es mi propia opinión, si la gente no espabila nos hundiremos en toda la porquería sintética, la contaminación de la atmósfera, cambio climático y todo eso...» (E3)

Etorkizunerako egiten dituzten aurreikuspenetan, ikus daiteke nola arrisku biologikoek merkatu berdeari eragin diezaioketen. Gizarteen sekuritizazioaz hitz egiten den garaiotan, zientzialari sozialen korronte batek dio jada ez dela kontua arriskuak arrazionaltasunez kalkulatzea, baizik ez esperotakoa mahaigaineratzea, edozein mehatxu biologiko edo ingurugiro krisi leher daitekeen agertokiak eraikitzea (Tirado et al. 2014). Iruditeria kolektiboan hondamendiaren ideia eraikitzen da, apokalipsiaren kultura berri gisa definitua zenbaiten aldetik (Van Loon, 2002).

Alarmismoa, erantzunen bat eman beharra, egonezina... aurkitu dezakegu ildo dikurtsibo horren sostenguan. Hondamendia datorreneko mezuekin eta iradokizun apokaliptikoekin, ziurgabetasunez beterik dauden egoerak sortzen dituzte, non ezagutza zientifikoak eta adituen lanak botere erabatekoa erdiesten duten. Biztanleriaren baitan beldurra ekoiztuz, kudeagarriago bihurtzen dira gizarte taldeak, dakitenen irizpideak jarraitzeko borondate irmoa erakutsiz. Ziurgabetasuna eraikitzean, etorkizun posibleak irudikatzen dira. Garrantzitsua ez da gertatuko diren edo ez, probabilitatea altua edo baxua den, baizik gizartearen barrunbeetan lor daitekeen konfiantza maila.

Green economy sonatuak badu aldaketa klimatikoak dakarren mehatxuari aurre egiteko nahia atzean, diskurtsoetan igarri ahal izan dugunez. Neurri batean bederen, aurrez aipaturiko sare zientifiko-burokratiko ofiziala darabil, gizarteak mehatxuari erantzuten ari direla irudikatzeko.

Azken finean, neoliberalismoak garatu duen mekanismo sofistikatu gisa interpreta dezakegu green economy-a. Batzuk, kapital metaketarako eta merkatu berriak sortzeko balio duela defendatu dute (Leonardi, 2012), bestetzuk kudeaketa bipolitikorako tresna eraginkor gisa definitu dute. Geure kasuan, faktore konplexu ugari lotzen dituen gailu sozial bezala definituko dugu green economy delakoa, zeinak ingurugiro krisiaren garaian, biztanleriaren kudeaketa biopolitikoa, merkatu berrien eraikuntza eta subjektibazio modu garaikideak elkarlotzen dituen, arrakastaz gehientsuenetan.

\section{ZENBAT DU GREEN ECONOMY-AREN PROPOSAMENAK ERALDATZAILETIK?}

Aztertu berri dugun mekanismo sozialak deskribatu ondotik, ezin daiteke esan praktika eraldatzailea denik ekonomia berdearen baitan garatzen diren kontsumitzeko eta ekoizteko moduak. Jasangarritasunaren eta ingurugiroaren hobekuntzaren gainean eraikiriko diskurtsoak desberdintasun sozialak areagotzen ditu. Ez da soilik praktika hegemonikoen 
baitan kokatzen, egungo aberastasunaren birbanaketaren logika elikatzen du, talde sozialen arteko arrakala hauspotuz, oharkabean bada ere.

Aztertu ahal izan dugunez, green economy-a agertzeko baldintzen artean, azken urteetan Europako hiri nagusiek jasan dituzten eraldaketak daudela, euren neoliberalizazioan sakonduz batik bat. Gentrifikazio prozesuei abiadura eman die, talde sozial xumeenen bazterketa posible eginez. Interesgarria zaigu hortaz, azpimarratzea green economy deritzonak nola eragiten duen hiriguneen eta gizarte klaseen arteko harremanean.

Gorago aipamena egin diegun nazioarteko klase ertain-altuek ekintzailetza berderako eremu emankorra aurkitu dute hiriguneetan, oraintsu arte herri-klaseak bizi zirenetan, zenbait kasutan, Bartzelonako ereduan ikusgarri zaigun bezala. Azken buruan, bazterketa prozesuak elikatzen dabiltza, eros-ahalmen altuko jendea erakarriz mugitzen diren inguruetara eta desberdintasun sozialak are gehiago urrunduz. Green subjektuak euren buruak eraldatzailetzat jo arren, euren praktikaren ondorio zuzenek ez digute esaten eraldaketa sozialaren bidean dagoenik, ezta urrik eman ere. Beste ikerketa bat legoke hor, baina hemen dagoneko zantzu batzuk antzeman ditugu. Alegia, gizarte segregazioa areagotu dezakeen prozesurik ez du oztopatzen, berau ureztatzen du, elikagaien kalitatea eta apaingarri estetikoak ekarriz kontsumitzaile mokofinentzat.

Bestalde, green mundu berri horren zabalpena ahalbidetu duen prozesua, jardun biopolitiko eta ethopolitikoa izan da. Aldaketa klimatikoaren gaineko diskurtso apokaliptikoa erabiliz, edozer gerta litekeen agertokiak eraiki dituzte, geure existentzia erabat babesgabe agertuz. Alarmismo sozial horrek, merkatu berrien irekiera erakarri du, green economy hau horren adierazleetako bat izanik.

Geure buruak begirada sozialetik etengabe epaitzen ditugun neurrian, «ni»-a hobetzeko desira haziz eta haziz doan garaiotan, gizarteko kide eraginkor eta arrakastatsua izan gura dugu. Diskurtso zientifikoak ezartzen dituen marko etikoen barruan jardunez, geure gorputzen perfekzioaren bilaketa martxan dago, geure bizitzak eta gorputzak gobernatzeko era bat nagusitzen da, funtsean. Green economy-a beraz, osasunaren eta kalitatezko produktuaren ideiari loturik, aipatu berri dugun gobernatzeko modu horren jardunean ederki egokitzen da, gizarte ethopolitikoaren eraikuntzan eragile aktibo bihurtuz.

Bi prozesuok, ordenamendu normatibo neoliberalaren baitan, egin dute posible green economy-aren arrakasta eta zabalpena. Ondoriozta dezakegu, hortaz, bere jatorria gorputzak eta bizitzak kudeatzeko erregimen bati eta agertoki mehatxagarri, ziurgabeen eraikuntzari zor diola.

Elikadura burujabetza edo agroekologia moduko proposamenetatik urrun xamar geratzen da (Azkarraga, 2014), herrigintzaren kontzeptua eta komunitatea ikuspuntu eraldatzailetik eraikitzeko beharra ez baitzaigu inondik ageri. Ecological Modernization Theory gisako proposamenen aurrean, geure ikerlanean ohartu gara egiteko eta ekoizteko ohiko moduak 
(nazioarteko merkatuaren logikapean, esan nahi baita) ez direla zalantzan jartzen, eta bere logika propioak, bizi ditugun erronka eta problematika sozioekologikoak elikatzera daramala, modu batez edo bestez (desberdintasun sozialak, prekariotasuna, ekoizpen industrial masiboa supermerkatu ekologikoen kate erraldoien kasuan...). Honenbestez, ezingo genuke esan ahalmen eraldatzailea duenik green growth, green market edo oro har green economy-ren proposamenak.

Ikerlanean zehar "mundu bizigarriago» baterako nahia eta hari diskurtsiboa identifikatu dugun arren, green kontsumoak ekar ditzakeen onura ekologikoez jakitun, berau posible egiten ez duen logika akumulatibo hazkor batean murgildurik daude subjektuok, sarraski sozial eta ekologikoak eragiten dituen merkatu logika berbera, hain zuzen ere. Egon litezkeen kritika sistemiko oro arintzeko funtzioa ere betetzen du, kokapen ekosozialistetatik etor zitezkeenak bereziki. Alabaina, green eragileetako zenbaitek euren burua bai jotzen dute eraldatzailetzat zentzu batean, sinetsiz gizarte errealitate ekologiko justuago eta emankorrago batera iristeko prozesuan laguntzaile direla. Kapital globalaren jario etengabeak munduko aberastasun ekonomikoa esku gutxi batzuen esku gera dadin ahalbidetzen duela frogatu digute izen handiko ekonomialariek (Piketty, 2014). Hala, merkatu berdeen antolakuntza egiturak berak, supermerkatu kate zabalen bidez antolatuz eta fakturazioa esponentzialki hazteko borondatea erakutsiz ${ }^{5}$, metaketa prozesu honi abiadura eransten dio.

\section{ZENBAIT ONDORIO}

Veritas supermerkatu ekologikoen kateko sortzaileetako bati duela gutxi eginiko elkarrizketa batean, bere arrakastaren inguruan galdetzen diolarik kazetariak, hala dio; kalean lurrera begiratzen duen jendeak sekula ezingo ditu aukerak ikusi. ${ }^{6}$

Burutu dugun ikerketan, merkatu berdearen, edo gehiagotan erabili dugun green economy-aren arrakastaren gako sozialak non dauden arakatu nahi izan dugu, zein prozesuk elikatzen duen eta zeintzuk diren bere agerpenerako baldintza sozialak ezagutu guran. Prozesu sozial eraldatzaileekin izan dezakeen harremanaren inguruan ere hausnarketa eta ikuspuntu bat plazaratu dugu.

Ikerketan zehar, alde batetik kultura urbano edo gizarte taldeen bereizketa prozesuez hitz egin dugu, green economy-a bera izanez, prozesu hori hauspotzen duen eragileetako bat. Hala, kapitalismo garaikidearen baitan diharduen aparatua izaki, desberdintasun sozialak areagotu eta kapitalaren prozesu akumulutiboa elikatzen du. Iruditzen zaigu esan dezakegula kontsumo eko-berde honen praktikaren, eta ezberdintzea posible egiten duten prozesu sozialen artean lotura estua egon badagoela. res, con 10 nuevas aperturas en 2018».
} 
Bestalde, biztanleriaren gaineko kudeaketa moduez mintzo gara, green economy-aren arrakastak zerikusia edukiz gorputza eta osasuna ulertzeko modu zehatz batekin, etengabeko hobekuntzan murgildua, norberaren gaitasun kognitibo eta fisikoak areagotu nahian uneoro. Lan merkatuak eska diezazkigukeen subjektibotasunak ekoitziz, green economy-a ordena normatibo neoliberalaren efektu gisa ere ulertzen dugu, ekintzailetza eta negozio grinaren logika identifikatu baitugu diskurtsoetan.

Aipatu bi prozesuok uztartuz, negozio berdea loratu dadin baldintza ezin aproposagoak sortzen dira, batez ere hiri identitate zehatz batzuen harreman sareetan, kontsumo subjektibaziorako tresna bilakatu baitute.

Hau esanik, green economy-ak izan ditzakeen potentzialtasunak hartu behar ditugu kontuan, martxan dauden bestelako proposamen eraldatzaileekin (ikuspuntu agroekologikoa edo elikadura burujabetzaren kontzeptua esaterako) nola nahasi daitekeen aztertzeko. Ondorioztatzen dugu, green economy-aren agerpenak ekosozialismoaren perspektibatik edo ikuspuntu eko-eraldatzaileetatik egin daitezkeen oposizioak desagerrarazten dituela, edo neurri nabarmenean murriztu. Hortaz, ekintza bateratu eta antolatuaren beharra dauka, maila ekonomiko, politiko, mediatiko eta akademikoan bere burua birdefinitzeko, eta sor ditzakeen egiteko modu berritzaileak, gizartearen eraldaketarako bidean jartzeko.

Finean, datozen hamarkadatan gizarte gisa dauzkagun erronkak horren erraldoien aurrean, ekoizteko, kontsumitzeko, egiteko eta harremantzeko modu jasangarriagoen eta eraldatzaileagoen bilakuntzan, green economy-ak badu esateko zerbait.

\section{ERREFERENTZIA BIBLIOGRAFIKOAK}

Azkarraga, J. (2014). «Harrigintza» berria. Apunteak hazkunde-osteko euskal herrigintzaz. Jakin, n. ${ }^{\circ}$ 202, pp. 11-43.

Bauman, Z. (2007). Modernidad líquida. Buenos Aires: Fondo de Cultura Eeconómica.

Bauman, Z. (2007). La vida en consumo. Buenos Aires: Fondo de Cultura Económica.

Bauman, Z. (2017). Retrotopía. Barcelona: Paidós Estado y Sociedad.

Benton, T. (2002). Social Theory and ecological politics: Reflexive modernization or green socialism?. In Dunlap, RE. Buttel, FH. Dickens, P. Gijswijt A. (eds) Sociological Theory and the Environment: Classical Foundations, Contemporary Insights (pp. 252-273) Lanham, MD: Rowman \& Littlefield.

Bina, O. (2013). The green economy and sustainable development: An uneasy balance? Environment and Planning C: Government and Policy , vol. 31, n. ${ }^{\circ}$ 6, pp. 1023-1047. 
Bourdieu, P. (1999). Meditaciones pascalianas. Barcelona: Anagrama.

Bourdieu, P. (2000). Poder, derecho y clases sociales. Bilbao: Desclée De Brouwer.

Brand, U. (2012). Green Economy - the Next Oxymoron? No Lessons Learned from Failures of Implementing Sustainable Development, GAIA, n. ${ }^{\circ} 21$, pp. 28-32.

Castel, R. (2002). La metamorfosis de la cuestión social. Una crónica del salariado. Barcelona: Paidós Ibérica.

Castells, M. (2003). La sociedad red. Madrid: Alianza editorial.

Cohen, M. (1997). Sustainable development and ecological modernisation: national capacity for environmental reform. OCEES Research Paper , n. ${ }^{0}$ 14, pp. 103-128.

Davies, A. Mullin S. (2011). Greening the economy: Interrogating sustainability innovations beyond the mainstream. Journal of Economic Geography, vol, 11, n. ${ }^{0}$ 5, pp. 793-816.

Deleuze, G. Guattari, F. (1987). Capitalisme et schizophrénie. Paris: Minuit.

Foster, J.B. (1999). Contradictions in the universalization of capitalism. Monthly Review, n. ${ }^{\circ} 11$, pp 29-39.

Foucault, M. (2006). Seguridad, Territorio, Población. Buenos Aires: Fondo de Cultura Económica.

Foucault, M. (2009). Nacimiento de la biopolítica. Curso del collège de France (1978-1979). Barcelona: Akal.

Fraser, S. (2015). The age of Acquiescence. Little: Brown and Company.

Gerring, J. (2004). What is a case study and what is it good for? American Political Science Review, n. ${ }^{\circ}$ 98, pp. 341-354.

Gibson-Graham JK (2008). Diverse economies: Performative practices for «other worlds». Progress in Human Geography, n. ${ }^{\circ}$ 32, pp. 613-632.

Givens, J.; Jorgenson, A. (2015). The Changing Effect of Economic Development on the Consumption-Based Carbon Intensity of Well-Being, 1990-2008. PLOS ONE, n. ${ }^{\circ} 10$, pp. 1-14.

Gould, K.A. Pellow, DN. Schnaiberg, A. (2008). The treadmill of production: Injustice and unsustainability in the global economy. Boulder, CO: Paradigm Press. 
Huber, J. (1991). Ecological modernization: Beyond scarcity and bureaucracy. New York: Routledge.

Jackson, T. (2009). Prosperity Without Growth?. London: Sustainable Development Commission.

Jolink, A. Niesten, E (2013). Sustainable development and business models of entrepreneurs in the organic food industry. Business Strategy and the Environment n. ${ }^{\circ} 24$, pp. 386-401.

Lasch, C. (1999). La cultura del narcisismo. Barcelona: Andres Bello.

Lash, S. Urry, J. (1998). Economías de signos y espacios: sobre el capitalismo de la posorganización. Buenos Aires: Amorrortu.

Laval, C. Dardot, P. (2013). La nueva razón del mundo. Ensayo sobre la sociedad neoliberal. Barcelona, Gedisa.

Leonardi, E. (2012). Per una critica della green economy neoliberale. Cultura della sostenibilità, n. ${ }^{\circ}$ 9, pp. 30-46.

Lewis, S.L. Maslin, MA. (2015). Defining the anthropocene. Nature, n. ${ }^{\circ}$ 519, pp. 171-180.

López Gay, A. (2008). Canvis residencials i moviments migratoris en la renovació poblacional de Barcelona. Barcelona: Consell de Treball Economic i Social de Catalunya.

Lorey, I. (2016). Estado de inseguridad. Gobernar la precariedad. Madrir: Traficantes de sueños.

Lupton, D. (2016). The Quantified Self. London: Polity.

Miller, D. (2005). Acknowledging Consumption. London: Routledge.

Mol, A. Spaargaren, G. (2002). Ecological Modernization and the Environmetnal State. In Mol, A. Buttel, F. (ed.) (2002) The Environmental State Under Pressure (pp. 33-52) Oxford: Elsevier Science.

Musu, I. (2010). Green Economy: great expectation or big illusion?, SSRN Electronic Journal, n. ${ }^{\circ} 15$, pp. 21-32.

Nijkamp, P. (2003). Entrepreneurship in a modern network economy. Regional Studies n. ${ }^{\circ} 37(4)$, pp. 395-405.

O’Neill, K. Gibbs, D. (2016). Rethinking green entrepreneurship - Fluid narratives of the green economy. Environment and Planning A , vol. 48, n. ${ }^{\circ}$ 9, pp. 1727-1749. 
OECD (Organisation for Economic Co-operation and Development) (2011). Towards green growth. Paris: OECD.

Pellizzoni, L., (2004). Responsibility and environmental governance. Environmental Politics n. ${ }^{\circ} 13$, pp. $541-565$.

Philips M (2013). On being green and being enterprising: Narrative and the ecopreneurial self. Organization, vol. 20, n. ${ }^{\circ}$ 6, pp. 794-817.

Piketty (2014). El capital en el siglo Xxı. Madrid: Fondo de cultura económica.

Renduéles, C. (2013). Las paradojas de la cultura crítica. Las clases creativas como intelectualidad orgánica del capitalismo postfordista. Sociologia histórica. n. 17, pp. 19-25.

Redclift, M., Woodgate, G. (1997). The International Handbook of Environmental Sociology. London: Edward Elgar.

Rose, N. (2006). The Politics of Life Itself: Biomedicine, Power, and Subjectivity in the TwentyFirst Century. London: Princetown university press.

Sennet. R. (2000). La corrosión del carácter. Barcelona: Anagrama.

Schaltegger, S. (2002). A Framework for Ecopreneurship: Leading Bioneers and Environmental Managers to Ecopreneurship. Greener Managament International, n. ${ }^{\circ}$ 38, pp. 45-58.

Schnaiberg, A.; Gould, K.A. (2000). Environment and society, the enduring conclict. Caldwell, NJ: Blackburn press.

Slocombe, D.S. (1998). Lessons from experience with ecosystem-based management. Landscape and Urban Planning n. ${ }^{\circ}$ 40, pp 31-39.

Tienhaara, K. (2014). Varieties of green capitalism: Economy and environment in the wake of the global financial crisis. Environmental Politics, n. ${ }^{\circ} 23$, pp. 187-204.

Tirado, F. (2008). La semántica de la biopolítica. Athenea Digital. n. o 14, pp. 331-338.

Tirado, F.; Baleriola, E.; Amaral Giordani, T.; Torrejón, P. (2015). Subjetividad y subjetivadores en las tecnologías de bioseguridad en la Unión Europea. Polis e Psique, vol. 4, n. ${ }^{\circ}$, pp. 23-50.

Tirado, F.; Torrejón, P.; Baleriola, E.; Maureira, M. (2016). El estatuto de las imágenes en psicología social contemporánea. Revista SOMEPSO, vol. 1, n. 1, pp. 25-47. 
Green economy, subjektibotasun berdeak? Begiratu soziologikoa | Jokin Bergara Eguren

UNEP (United Nations Environment Programme) (2011). Towards a green economy: Pathways to sustainable development and poverty eradication. Nairobi: UNEP.

Van Loon, J. (2002). Risk and Technological Culture. London: Routledge.

VanWynsberge, R. Khan, S. (2007). Redefining case study. International Journal of Qualitative Methods, vol. 6, n. ${ }^{\circ}$ 2, pp. 80-94.

Yin, R. (1994). Case study research: Design and methods. Thousand Oaks, CA: Sage. 